FILOLOGÍA FRANCESA 



\title{
PASO DEL TIEMPO Y REFORMULACIONES DISCURSIVAS: EL SIGLO XV Y EL SIGLO XVII, DOS MOMENTOS DE TRANSICIÓN EN LA LITERATURA FRANCESA.
}

\author{
María Pilar SuÁREZ \\ Universidad Autónoma de Madrid \\ pilar.suarez@uam.es
}

\section{REsUMEN}

El paso del tiempo impone con su ritmo desfases y desgastes, y el discurso literario es sensible a esas discordancias. Las formas discursivas acusan en efecto ese movimiento, sobre todo cuando se trata de períodos identificados como «de transición»: asistimos entonces con frecuencia a la recuperación diferencial de modelos discursivos precedentes, en una acción que parece poner en cuestión antiguos universos de sentido, así como los presupuestos que a ellos subyacen.

Los siglos XV y XVII proporcionan ejemplos excelentes al respecto: pese a la diferencia existente entre ambas épocas, reconocemos en ellas la coincidencia de estrategias discursivas de reformulación que se hacen eco de una perspectiva marcada por cierto escepticismo, vinculado éste a una conciencia de finitud. Al mismo tiempo, en dichas construcciones se advierte un movimiento de búsqueda de formas nuevas que tratan de dar respuesta a nuevas aprehensiones del hombre y de sus modos de inscribirse en el espacio y en el tiempo. Le Petit Jehan de Saintré de Jean de la Sale y la Histoire Comique de Francion de Charles Sorel nos permitirán ilustrar esta dinámica.

Palabras Clave: Jehan de Saintré, Francion, barroco, transición, parodia, cortesía, humanismo, novela, relato breve. 


\section{RÉSUMÉ}

Le passage du temps impose des décalages et des affaiblissements avec son rythme forcé : le discours littéraire se rend attentif à ces discordances. Les formes discursives en accusent en effet les conséquences, notamment lors des périodes susceptibles d'être identifiées comme "de transition »: nous y assistons à une reprise différentielle des modèles précédents, une démarche qui obéit en quelque sorte à la mise en question des anciens univers de sens et de leurs présupposés.

Le XVe et le XVIIe siècle constituent des exemples significatifs de ces dynamiques. En dépit des différences entre les deux époques, nous repérons des coïncidences remarquables en ce qui concerne la présence de configurations discursives, qui par la voie de la distorsion des formes préalables se font écho d'un mouvement d'instabilité, d'une conscience de finitude. Or, ces constructions discursives sont également imbues d'un mouvement orienté vers la quête de nouvelles configurations, susceptibles de répondre aux reformulations de l'homme et des rapports quil entretient avec son espace et son temps. .Le Saintré de Jehan de la Sale et le Francion de Charles Sorel nous permettront d'illustrer cette hypothèse.

Mots CLÉ : Jehan de Saintré, Francion, baroque, transition, parodie, courtoisie, humanisme, roman, nouvelle.

El paso del tiempo impone desfases y desgastes con su ritmo, y el discurso literario permanece atento a esas discordancias. Las formas discursivas acusan en efecto ese movimiento, sobre todo cuando se trata de períodos considerados «de transición». En ellos el hombre se debate de modo muy particular entre la conciencia de finitud que el paso del tiempo imprime en los grandes valores sobre los que se ha venido construyendo su mundo y la búsqueda de propuestas alternativas a éste. Muchas de las dinámicas discursivas que emergen en dicho contexto de cambio lo hacen a partir de formas literarias vinculadas en su origen a tiempos pretéritos, -convocados éstos más o menos implícitamente por los distintos autores desde la nostalgia- y gestionadas desde una perspectiva diferencial: se produce así la contraposición -a menudo dilemática- entre dos instancias en el interior de un mismo proyecto, en la que el locutor retoma configuraciones que emanan de universos discursivos que muestran sus fisuras. Dichas formas son subvertidas en el interior mismo del discurso, a menudo a través de la mezcla y la contraposición de tonos. Tiene así lugar un proceso de hibridación en el que estalla un universo de sentido que se muestra desgastado, para desde ese estallido buscar nuevas posibilidades discursivas.

Este juego de reformulaciones tiene una marcada trascendencia en los distintos rostros que va adquiriendo el «héroe», -término del que nos servimos en un sentido amplio para aludir a las distintas elaboraciones que del hombre y lo humano tienen lugar en cada época-, y en la manera en que éste es mostrado ora desde su completitud, ora desde sus contradicciones, resueltas en cada momento de modo desigual.

Nos acercaremos a dos momentos, diferentes, que tienen en común su condición de «momento de tránsito»: por un lado, la segunda mitad del siglo XV, donde advertimos una reformulación del héroe cortés, forjado en el siglo XII desde una perspectiva que en- 
globaba las facetas guerrera y emocional del hombre, en cuyo proceso de construcción la figura de la Dama jugaba un papel decisivo.

El siglo XV ofrece, en efecto, testimonios literarios que muestran las fisuras producidas en el universo discursivo cortés, y en ese contexto Le Petit Jehan de Saintré no deja de mostrar la cortesía en su versión más degradada. Pero junto con ella también la reorientación que en el interior de la propia obra se produce hacia un modelo de héroe nuevo, configurado de acuerdo con parámetros que emanan de la corriente humanista que renace y se consolida en la Francia del siglo XVI. En dicho marco surge un modelo humano que se define por la multiplicidad, así como por su capacidad, y su libertad, para gestionarla y canalizarla. El resultado es una aprehensión totalizadora y englobante del hombre.

Desde esas consideraciones nos dirigiremos hacia el primer tercio del siglo XVII para detenernos en la Histoire Comique de Francion, de Charles Sorel, donde identificamos los últimos resquicios de esa dinámica humanista que habíamos advertido de modo incipiente en el Saintré. En el Francion el héroe soreliano se halla inicialmente caracterizado por la fuerza que le confiere esa su condición polifónica convenientemente canalizada, para más adelante, en la segunda parte de la obra, mostrar su disgregación en medio de contradicciones no resueltas.

Una y otra obra nos permitirán ilustrar en dos momentos distintos -el siglo XV y el XVII- esos procesos de construcción y disolución de modelos humanos, y literarios, que aun en épocas diferentes cobran cuerpo a través de estrategias discursivas en las que podemos reconocer cierta afinidad.

\section{LA CORTESÍA: ESE PRIMER GARANTE}

Una de las primeras manifestaciones de este juego de reformulaciones podemos en efecto situarlo en torno a las modulaciones que se produjeron a partir de la cortesía y lo cortés.

Pocas nociones vinculadas al universo de sentido medieval son tan conocidas, y tan difundidas, como lo fue la cortesía. Una noción rica y plural en sus acepciones y sus posibilidades semánticas, y cuyas modulaciones, y riqueza, tuvieron tanto que ver con sus desplazamientos geográficos.

Dichos desplazamientos se tradujeron en efecto en cambios producidos dentro de las condiciones de aprehensión y elaboración de algunos topoi que le están vinculados: se trata por tanto de una recuperación discursiva que implica una acción interpretativa previa, susceptible de introducir variaciones en los valores convocados con respecto a su universo de sentido originario.

La fin amors implicaba ya desde sus orígenes en el territorio de Lengua d'Oc un enriquecimiento del héroe a través del desarrollo de su vertiente emocional. En su adaptación a las regiones del norte, sobre todo en el marco de la novela, el amor cortés, la cortesía, será aprehendido como sistema de valores culturales, sociales que tratan de articular una fusión entre la función guerrera y fundadora -por ende social- del héroe y su aspecto personal-sentimental. Una dinámica de integración que, a diferencia de su articulación en el sur, desemboca en el matrimonio, aprehendido éste como opción que garantiza la estabilidad social y política (Accaire, 2004). 
Como acabamos de apuntar, estas creaciones y recreaciones de lo cortés permitieron construir un modelo heroico caracterizado por la unión de contrarios en el seno del humanismo del siglo XII ${ }^{1}$. Es en ese contexto donde se produce la emergencia del roman, que responde al deseo de elaborar una «épica del individuo«, en la que queda canalizado todo cuanto puede de alguna manera tornarse para éste agente de dispersión ${ }^{2}$.

A lo largo del siglo XIII estos parámetros coincidieron, en el espacio y en el tiempo, con otras elaboraciones del hombre aprehendidas desde perspectivas distintas, que no ocultan sus contradicciones ni su dispersión. Nacen formas poéticas nuevas, algunas de las cuales gestadas por oposición a los moldes corteses, así como otros géneros que se desarrollan en el marco de la sociedad urbana, del que el teatro constituye tal vez el ejemplo más representativo.

Ahora bien, el que esas formas literarias no se desarrollaran en el núcleo del universo discursivo cortés no se tradujo en una ignorancia total de sus parámetros retóricos por parte de éstas: los tipos, motivos, situaciones... son retomados desde una perspectiva diferencial a través de la cual son mostradas las fallas de los grandes modelos a los que inicialmente estaban referidos, y frente a los cuales las formas discursivas nacientes no dejan de de posicionarse. Será una época en la que comenzamos a observar la coexistencia, incluso la confrontación de lógicas, los juegos de identidad, las superposiciones entre sueño y realidad enunciados desde la dificultad que existe para definir los contornos.

Recordemos en este sentido que en Le Jeu de la Feuillée el personaje central, cuyo nombre coincide con el del autor, se define de acuerdo con una realidad virtual: el sueño de alcanzar la fama y el renombre en París, mientras se debate entre la visión de su esposa antaño forjada desde los parámetros del amor cortés, y su percepción actual de ésta filtrada por una perspectiva misógina. El personaje proyectado hacia un punto de fuga permanece anclado en su espacio cotidiano por el que desfilan personajes, situaciones casi fantasmagóricas, que son retazos de ideales pasados. La conciencia de confusión del personaje central se sitúa en un marco en el que los grandes referentes culturales -la cortesía, las relaciones paterno-filiales- aparecen puestos en cuestión. Si Chrétien a finales del siglo XII había mostrado en su Perceval la canalización de la polifonía de su héroe después de haber mostrado la vertiente más destructiva de sus contradicciones, Adam de la Halle casi un siglo después construye un personaje que se debate entre grandes ideales situados fuera de su alcance, y su vida atrapada por la inmediatez de lo cotidiano. Adam aparece en la escena escindido entre una «realidad» vivida en sueños, y una «ilusión»,

\footnotetext{
${ }^{1}$ En lo que al papel que el universo discursivo del amor cortés ha podido jugar en la construcción de un discurso sobre el hombre, no podemos dejar de recordar el papel que la «prohibición» ha jugado en la construcción y la evolución del hombre. Tal como mostraron los trabajos de Lévi-Strauss (Lévi-Strauss, 1962) y de Radcliffe-Brown (Radcliffe-Brown, 1952), la prohibición que conlleva el tabú, integrada en una economía mítica y ritual, se revela una vía para canalizar los instintos biológicos y darles una forma específicamente humana. En este marco que ya identificamos en momentos ancestrales de la historia del hombre, entendemos oportuno situar la dinámica, de ascesis y canalización de los impulsos físicos y psíquicos, incluso sociales, que subyace en la concepción inicial del discurso cortés: un instrumento para la construcción de un modelo humano que integra la pluralidad y la complejidad del hombre en una visión elaborada desde una perspectiva ideal de completitud.

${ }^{2}$ La dinámica de síntesis, de integración de instancias que se hacía eco de la diversidad del héroe, en definitiva del hombre, a mediados del siglo XII, culminaba de algún modo en el Perceval de Chrétien, donde el héroe unía a su iniciación guerrera y cortés el desarrollo de su consciencia interior. Tiene así lugar el nacimiento de un personaje que reúne en sí mismo todas las instancias de lo humano.
} 
manifestada en la ironía del propio autor, homónimo, que parece negar a su héroe la capacidad de cumplirlas (Suárez, 2008, 2011a).

Este juego de variaciones no sólo se manifiesta en formas literarias que se muestran explícitamente diferentes con respecto a la producción existente hasta el momento: también se halla presente en obras identificadas como «Continuaciones», y nos referimos de modo especial a aquellas obras que nacían desde la voluntad de encontrar un final adecuado al inacabado Cuento del Grial. En efecto, el modelo de síntesis propuesto por Chrétien -donde el héroe unía a su iniciación guerrera y cortés el desarrollo de su consciencia interior- se va a ver modificado en ellas con la construcción de héroes configurados desde una perspectiva que los decanta bien hacia la proeza caballeresca instituida en su dimensión más mundana, o hacia una espiritualización progresiva en virtud de la cual el caballero acaba por abandonar el terreno de lo tangible en aras de una trascendencia excluyente. Se trata de continuaciones/ recreaciones que dan lugar a proyectos discursivos en los cuales se advierte la negación de aspectos esenciales de los textos iniciales. Podríamos citar otro ejemplo, aun en otro punto del campo literario: la continuación del Roman de la Rose asumida por Jean de Meun. Éste, explicitando una eventual intención de reanudar un proyecto precedente inacabado, retoma motivos y situaciones vinculados a la retórica cortés para desde ahí construir una argumentación que acaba por negar en sus mismos fundamentos el universo discursivo del que Guillaume de Lorris se había hecho eco. El suyo es un juego de retractación progresiva con respecto al espíritu de la cortesía, que se verá reemplazado por una visión «científica» del mundo, imbuida de filosofía natural.

Una suerte de reciclaje discursivo que ya entonces se traduce en rupturas y reformulaciones de formas literarias vinculadas a otros universos de sentido -convocados más o menos implícitamente por los distintos autores desde la nostalgia- y gestionadas desde puntos de vista a menudo divergentes: se produce así la coexistencia de instancias -no necesariamente afines- que hace estallar desde dentro un modelo discursivo y que conduce a formas nuevas que hacen posible la enunciación de elaboraciones humanas y culturales nuevas también.

\section{EL SIGLO XV: UN PUNTO DE INFLEXIÓN EN LA CONSTRUCCIÓN DEL HOMBRE}

Este proceso que advertimos en el siglo XIII, y en el que hemos abundado en trabajos precedentes (Suárez, 2011b), se deja también sentir, tal vez con mayor claridad si cabe, en el siglo XV, momento en el que se gesta un cambio que se revelará sustancial en el devenir cultural del hombre: nos detendremos de manera especial en Villon, en el modo en que contribuye a la renovación de la poesía, siguiendo la dinámica ya inaugurada por algunos de sus predecesores del siglo XIII, a partir de las distorsiones que realiza en los modelos discursivos corteses; y en Antoine de La Sale, que en su Saintré establece la transición del «roman » a la «nouvelle » también desde el juego con una cortesía que parece devaluarse.

En efecto, François Villon construye en el siglo XV una poética a partir del juego paródico con formas pertenecientes a la retórica cortés. Juegos de instancias, de puntos de vista encontrados que parecen hacer estallar desde dentro una forma discursiva: contra- 
posición de diferentes universos de sentido, a menudo asociados con dos tonos, dos ethos, en cuyo marco el decurso del tiempo es enunciado en una palinodia que da cuenta de la empresa de búsqueda de nuevas formas.

Desarrollando los parámetros del dit, forma creada por poetas del siglo XIII que erige en personaje al locutor principal del poema a través de la primera persona, la poesía de François Villon se sustenta en el diálogo entre un yo proteiforme, y un juego de puntos de vista externos, al menos en apariencia, a ese yo, que acentúan la dimensión polifónica del texto. Su discurso, el Testamento, se encuentra estrechamente vinculado al paso del tiempo en cuyo marco el locutor se enuncia. Una enunciación construida en clave de decadencia, que muestra la degradación física y moral, desde un espacio limítrofe en el cual se sitúa -«Qui meurt a ses loix de tout dire» (LXX).

El locutor principal pone en pie una serie de instancias discursivas sobre las que se proyecta, y otras a las que identifica como rostros del Fatum que lo zarandea y destruye. En el primer caso se trata de personajes o tipos a los que se presupondría una condición de garante -espiritual, moral-, algunos de los cuales sin embargo se ven afectados por el mismo paso del tiempo que golpea al «yo» principal (Ballade à sa mère), una muerte social que se traduce en exclusión, o en una muerte a sus propios empeños, vinculada al motivo del tempus fugit.

Ese Chronos devorador queda magníficamente recogido en las emblemáticas Ballade des Dames du temps jadis, cuyo estribillo evoca las «nieves de antaño», y Ballade des Seigneurs du temps jadis, que recuerda desde la nostalgia la ausencia de los grandes héroes: «Mais ou est le preux Charlemagne», avanzada en el primer verso de la estrofa XXIX del Testamento «Ou sont les gracieux gallans» (XXIX)... y retomado en el estribillo de la Ballade en vieil langage françoys «Autant en emporte ly vens».

En ese marco la degradación del amor y de la mujer supone una constante discursiva: la ruptura del discurso cortés mediante el juego con términos pertenecientes al campo léxico de partes del cuerpo en el que contrapone el «corazón», vinculado al sentimiento y la emoción, con otras vísceras: «je ne luy laisse ne cuer ne foye» (XC). A partir del mismo campo léxico - partes del cuerpo-, se generan dos isotopías semánticas diferentes que interactúan desde una relación antitética a partir de la cual se advierte la distorsión del discurso amoroso. El tono bajo se impone sobre el tono elevado que a tales discursos se presupone: ése es el recurso empleado en la Ballade de Villon à s'amye, una exhibición de dominio de la retórica amorosa que el locutor se esmera en subvertir verso a verso en la primera estrofa:

Faulse beauté qui tant me couste chier

Rude en effect, ypocrite doulceur,

Amour dure plus que fer a maschier,

Nommer que puis, de ma desfaçon seur,

Cherme felon, la mort d ung povre cuer,

Orgueil mussié, qui gens met au mourir,

Yeulx sans pitié, ne veult Droit de Rigueur,

Sans empirer, ung povre secourir? ${ }^{3}$

${ }^{3}$ El subrayado es nuestro. 
La Domina, la Maîtresse, no se revela en este caso lejana por su excelencia, sino por su traición. Una traición vengada por el propio François en la tercera estrofa de la balada mediante un nosotros implícito donde víctima y verdugo acabarán por compartir la decadencia moral y física. Asistimos a una retractación ante las propias decisiones iniciales de fidelidad y sometimiento, planteadas como la consecuencia lógica ante la negación de la acción benéfica de la mujer, de su papel en la construcción del héroe, al que antes nos habíamos referido como inherente a la cortesía. Bien al contrario la mujer es ahora enunciada como avatar del tiempo, así como eventual víctima de su paso (Suárez, 1998). Se ha producido una negación de la Amiga, no de los valores trasladados por el discurso cortés en sí: de hecho, el personaje de ésta es presentado a modo de contraejemplo, frente al cual el locutor manifiesta sus distancias cuando en la última de las estrofas, el envío, se dirige al Príncipe, al que instituye en garante de lo cortés dentro de la balada, y a cuyo juicio somete la actitud de la Dama a partir de un conector concesivo:

Mais tout franc coeur doit par Nostre Seigneur

Sans empirer ung povre secourir

Desde este tenor, Villon menciona en su Testamento otras obras que también suponen una «contra-enunciación» paródica -no necesariamente cómica- del amor cortés, de entre las cuales destaca La Belle Dame sans Mercy de Alain Chartier, donde se pone de manifiesto la deformación de este esquema.

Item je donne aux amans enfermes/sanz le laiz Alain Chartier/a leurs chevez de pleurs et lermes/Trestout fin plein ung benoistier/Et ung petit brain d esglantier/Qui soit tout vert, pour guipillon, (CLXVIII)

Como acabamos de señalar, la de Villon es una poesía, si no dramatizada, sí construida a partir de la interacción explícita de varias voces que muestran un «yo» segregado en varios ethos, que se confronta con otros. En ese marco discursivo advertimos una mirada de añoranza sobre los grandes ideales elaborados por dicho discurso, opuestos al tiempo cotidiano aprehendido en su dimensión devastadora. La constatación de la inmanencia parece confrontarse a aspectos vinculados a la tradición en tanto que garante de las estructuras que rigen la vida comunal y la estabilidad del grupo, de tal modo que los comportamientos que se traducen en una ruptura de ese equilibrio son denostados, podríamos decir castigados, a través de la burla y la banalización.

Una crítica a menudo articulada a partir de una inversión que sitúa el discurso en el terreno de lo carnavalesco: podríamos en muchos casos hablar de una comicidad vinculada al charivari entendiendo este término como acción ritual que a través de la burla sanciona y castiga un comportamiento distorsionador con respecto a las normas y acciones que garantizan la estabilidad del grupo ${ }^{4}$.

Vía para la focalización de vicios sociales o de conductas consideradas impropias, el charivari, en su filiación con los ritos carnavalescos, no está exento de una perspectiva conservadora desde el momento en que son los ideales aristocráticos, tradicionales

\footnotetext{
${ }^{4}$ La traducción de charivari al castellano sería la de «guirigay», no obstante mantendremos este término a lo largo de nuestro trabajo en francés teniendo en cuenta que con él queremos aludir a un concepto antropológico. En lo que a esta cuestión se refiere remitimos a los trabajos de Jelle Koopmans (Koopmans, 1997).
} 
-como ocurría en el discurso de Villon- los que funcionan como garantes de su argumentación.

Se trata de un esquema que podemos reconocer en obras de teatro ${ }^{5}$ contemporáneas al autor del Testamento, que gozaron de una gran popularidad entre el público de la época: nos referimos a las soties. Son éstas piezas que se hacen eco de las transformaciones que están produciéndose en la época, y en las que la doble naturaleza de la locura es explotada con el fin de mostrar una tensión dramática donde la retórica del sinsentido se pone al servicio de una argumentación que denuncia los procesos de mutación sufridos en la época, entrevistos en clave de degradación. Ello supone una evocación implícita del hermoso tiempo pasado, y añorado, al que se había referido Villon ${ }^{6}$.

Algunas de estas obras se articulan sobre el personaje de Bontemps, para ser más exactos sobre su ausencia, debida a las malas artes de Temps Nouveau, que a causa de su ambición sume al mundo en una situación de penuria. Los cambios que se producen en la sociedad de la época son pues entrevistos por los autores de estas piezas en clave de degradación.

Estas obras ponen asimismo el acento sobre una sociedad que sobrevalora la dimensión externa del hombre, en lo que podría ser una distorsión de la importancia que la cortesía había venido concediendo a la civilidad y al refinamiento de costumbres, en cuyo contexto cobra sentido el cuidado del cuerpo que se advertía en el personaje que presenta Guillaume de Lorris en la primera parte del Roman de la Rose. Un protagonismo excesivo conferido a lo suntuario ${ }^{7}$ donde el emblema deja de actuar de acuerdo con su función de reflejar una condición interna para cobrar valor en sí mismo.

En una dinámica que podríamos considerar como paralela a los recursos que Villon ya había puesto en práctica -el juego paródico a partir de formas literarias anteriores-, y a la subversión de valores denunciada por las formas dramáticas a las que brevemente nos acabamos de referir, el discurso novelesco -que ha vivido un proceso de saturación y desgaste-, también se sirve de la ruptura de formas precedentes -muchas de ellas vinculadas

${ }^{5}$ El XV se caracteriza por el protagonismo de la imagen -plástica y discursiva. Una cultura de lo visual, incluso de lo simulacral, donde el esplendor del fasto coexiste con las imágenes devastadoras de la muerte y del paso del tiempo. Podríamos hablar de una presencia de lo «virtual», que explica en buena medida el protagonismo que en aquella época adquiere el teatro y el espectáculo en general

${ }^{6}$ Muchas de las obras muestran la llegada de una nueva época en la que «Gens Nouveaux» prometen cambios en la sociedad para conseguir un mundo perfecto y utópico, para acabar poniendo al descubierto el engaño que subyace a tales proyectos: «Bontemps» ya ha pasado, y no volverá, y la «Gente nueva» no procurará beneficio alguno. Éste es el argumento central de la Sotie de Bontemps et Monde. Y el de la Farce des gens qui ménagent le Monde et le logent de Mal en Pire, una obra que data aproximadamente de 1461, y en la que se produce un desplazamiento dramático a través del cual «Gens Nouveaux» conducen al personaje de «Monde» del espacio de «Mal» al espacio de «Pire», en un recorrido plagado de alusiones y críticas dirigidas contra abogados, procuradores y agentes del orden. La presentación de la avidez y la avaricia de los personajes da paso a una mirada desencantada del mundo que se ve condenado a sufrir la rapiña «des vieux et des nouveaulx».

${ }^{7}$ En esta línea podríamos situar la Farce des Gorriers, en la que soldados que llegan arruinados de las guerras de Italia, deciden para obtener dinero convertirse en «gorriers»-«Grosses manches, Bonnet au dessus de l'oreille, et les chaussures des galants besogneux»-, esto es, personajes que pretenden vivir de apariencias e imponer sus hábitos como moda. El vestido de la simulación funciona como máscara física y moral desde la que actúan. Sus declaraciones de principios se muestran en una amplia letanía enunciada por Locura, que los convierte en instrumentos suyos. El personaje de «Folie» se muestra como fuerza que gobierna todo y a todos, y que con su ubicuidad alcanza el mundo entero: es éste un escenario que no dejará de recoger Erasmo en el Elogio de la Locu$\mathrm{ra}$, sobre todo cuando presenta el rostro más negativo de ésta. 
al universo cortés-, para hacer estallar lo que en un primer momento podría ser entrevisto como un relato inscrito en dichos parámetros tradicionales.

En estos momentos el roman pervive por un lado en recreaciones de los modelos artúricos, al tiempo que, por otro, se advierten intentos de abrir nuevas vías para crear una nueva «épica del individuo» en una época plena de cambios. En esa empresa jugará un papel importante un esquema narrativo desarrollado en Italia por Boccaccio, a partir del fabliau $^{8}$ : la nouvelle, nueva en su concepción, algo que por otra parte queda recogido en su propia denominación genérica, y que será recuperada por la literatura francesa a lo largo del siglo XV e inicios del XVI.

En el paratexto Jehan de la Sale ${ }^{9}$ identifica su Petit Jehan de Saintré como nouvelle pese a que su extensión superaba la de los relatos hasta entonces vinculados a dicho género. Sí tenía sin embargo en común con esos sus precedentes narrativos el doble nivel de narración introducido al final del relato en el marco del diálogo, y el hecho de que éste diera cuenta de hechos más o menos contemporáneos del narrador y que éste formula como verídicos.

Pero, como acabamos de apuntar, el Saintré no supone un cambio radical a primera vista: éste tendrá lugar a partir de la «mutación» operada en el interior de una narración que se ajusta al modelo novelesco tradicional para ir mostrando un mundo bastante más descarnado. Podríamos hablar de una hibridación entre los parámetros de una y otra forma, en la que se advierte cómo la adhesión inicial del narrador -y del personaje- a los esquemas narrativos tradicionales, con todo lo que ello conlleva, da paso a un proceso de retractación en el interior mismo de la narración, en el cual interviene una comicidad amarga con fines satíricos y desmitificadores, para desde ahí despegar hacia la construcción de parámetros narrativos diferentes.

A tal fin el locutor principal introduce una nueva instancia a través del personaje central, que en el interior de la narración se desdobla al tomar conciencia de la no validez de los presupuestos vitales sobre los que hasta entonces había venido sustentando su propia progresión y su condición de caballero y de hombre.

\footnotetext{
${ }^{8}$ Pese al predominio del tono bajo en la mayoría de estos relatos, el fabliau no constituye en sí una contestación al discurso cortés, ni siquiera una alternativa narrativa con respecto al roman, con el que coexiste. En sus orígenes dirigido al mismo público, el fabliau crea situaciones discursivas en las que se juega con la no pertinencia, la ruptura de expectativas e incluso la violencia física con el fin de garantizar la risa y el divertimento de su público muy a menudo a expensas de personajes más típicamente identificados con la dimensión pecuniaria del universo mundo burgués. Banqueros, comerciantes, taberneros..., avaros y por supuesto celosos, -todos ellos rasgos vinculados a una caracterización anticortés- son los personajes peor tratados en estos relatos: los personajes especialmente vinculados al dinero y a los negocios, que serían en las soties asimilados con los Sotz Nouveaux-, se encuentran en una relación de posición opuesta a la de los grandes señores, generosos, bien humorados...y corteses, vinculados a los valores tradicionales. Ese «Bontemps» que algunas soties recordaban con añoranza.

${ }^{9}$ Entre la corte de Anjou, en la que pasó cuarenta años, y la corte de Luxemburgo, más próxima a la sensibilidad de Borgoña, a la cual por otra parte nunca perteneció Antoine de La Sale, el autor de la obra se hace eco del gusto por el pretendido realismo y por lo licencioso de las nouvelles, término éste convocado en el paratexto, cuya pertinencia se ve progresivamente constatada en virtud de las situaciones y motivos que el narrador va incorporando (Jeay, 1997). Para la edición en francés remitimos a la llevada a cabo por J. Blanchard (La Sale, 1995a). Para la versión española a la edición de Felicia de Casas cuya impecable traducción y cuyas notas a pie de página constituyen una herramienta inapreciable para la lectura y comprensión de la obra, así como del contexto de transición en que ésta es elaborada (La Sale, 2000).
} 
El trazado inicial se sustenta sobre una serie de motivos y situaciones, moneda común en todo relato heroico: el joven muchacho, la dama, la hazaña, el amor, la fidelidad, el sometimiento a la voluntad de la dama... el secreto.

El personaje de la dama -que en virtud de su condición y edad, así como del papel que al principio asume, aúna los tipos de la amante y la madre- es construido de acuerdo con el estatus de la Domina ${ }^{10}$ llevado éste hasta las últimas consecuencias: excelencia, linaje elevado situado fuera del alcance del héroe, inexpugnable e imprevisible. Su acción mediadora entre el joven y la tradición cobra cuerpo en su acción compiladora desde la que retoma y filtra los tratados morales y corteses ${ }^{11}$.

Por su parte, el joven Saintré responde a un tipo de caballero que existe en la época en que La Sale escribe: no se trata de un personaje ajustado al modelo artúrico, sino de un tipo caballeresco al uso cuyas hazañas presentan similitudes con las que se atribuían a los héroes de las biografías caballerescas de la época -Jacques de Lalaing sería un buen ejemplo en este sentido. Michelle Szkilnik subraya que, contrariamente a las tesis de Dubuis, Saintré no es una incongruencia: su lugar está en el mundo refinado y preciosista avant la lettre de las cortes europeas descritas por el mismo La Sale, repletas de gloria mundana:

Exploits sportifs ou plus souvent vestimentaires, elles font du nouveau chevalier un dandy avant l'heure. Cet idéal certes est tout aussi inaccessible que celui du viril chevalier arthurien, mais d'une toute autre nature. Si Don Quichotte avait lu Saintré, il serait devenu non pas un chevalier errant épris d'aventures mais un courtisan habile à soutirer cadeaux, bourses et honneurs aux grands parmi lesquels il aurait évolué ${ }^{12}$.

En efecto, el Saintré no sigue ni el espíritu, ni los moldes de la narrativa artúrica, pero sí mantiene, siquiera como motivo, cuestiones vinculadas a la cortesía: de hecho, son los desplazamientos producidos en este terreno, focalizados en la figura de la Dama, lo que hace que esta obra sea un punto de inflexión dentro de la narrativa francesa. Un desplazamiento que tiene que ver con el posicionamiento del personaje femenino ante la cuestión de la libertad y la autonomía del héroe.

La acción, situada en un tiempo que se revela contemporáneo del narrador, no muestra la restauración de un tiempo ya lejano, y ejemplarmente mítico: antes bien la narración -junto con el raconto final que introduce un segundo nivel narrativo- desemboca en una suerte de constatación de cambios producidos en el tiempo presente. El plan-

\footnotetext{
${ }^{10}$ Mühlethaler afirma que Belles Cousines se construye sobre Dido, o cualquiera otra viuda ejemplar «du temps jadis» de entre las evocadas por Villon, desde cuya ejemplaridad inicial -que reúne el aspecto social y económico con lo moral- se produce un desplazamiento hacia el terreno del fabliau, que convoca su contrario: la matrona de Efeso del Satiricón, y que recupera a una Dido que resulta ser una curiosa fusión de viuda ejemplar y viuda alegre. (Mühlethaler, 2006)

${ }^{11}$ En sus discursos Belle Cousine recoge ejemplos de mujeres valerosas, cita fuentes vinculadas tanto a la patrística como a la filosofía antigua. Su discurso se hace eco de obras anteriores en su proceso de adoctrinamiento del joven caballero. Un adoctrinamiento donde el celo pedagógico del compilador se une al del maestro de armas.

${ }^{12}$ Tanto Lalaing como Saintré van configurando los rostros de una caballería distinta de la evocada por los personajes de buena parte de la producción novelesca de la época: y es que los caballeros de las novelas tardías del siglo XV tampoco poseían la fuerza y la pregnancia de los modelos artúricos tradicionales, pero mantenían las formas -pese a su pérdida de trascendencia (Szkilnik, 2003:155).
} 
teamiento inicial del roman ha ido mutando hasta llegar a la pointe, donde queda finalmente al descubierto la actitud manipuladora de la Dama, así como la inversión producida con respecto al punto de partida, y al universo de valores que ella misma evocara.

Como ya habíamos indicado -ver nota 1-, la prohibición que inicialmente, y desde la economía de lo cortés, podría actuar como instrumento de formación y canalización, acaba revelándose como herramienta de presión y manipulación en manos de la Dama, que mediante la imposición sistemática de su «autoridad» y sus deseos niega al individuo, aun cuando éste en todo momento se muestre proclive a mantener sus pactos de fidelidad. La función de ésta se ve claramente degradada, y ello abre un conflicto de alguna manera anunciado por el narrador en una prolepsis, no exenta de ironía, que contiene referencias temporales explícitas al final del capítulo 33: «Et par ainssy demoura cest amour ainssy secrete jusques ad ce que Fortune par la variableté de Madame, l'en voult le dos tourner, ainssy que aprés s'enssieut» (La Sale, 1995: 136) y al inicio del 34: Ceste amour anssy loyalle et secrette dura xvj ans» (La Sale, 1995: 136). En dichas afirmaciones se advierte una asociación explícita entre los vaivenes de Fortuna y el personaje de la Dama, hasta el momento referente e iniciadora del héroe en el terreno de la cortesía y la lealtad.

Los desfases comunicativos entre ésta y el joven, los discursos en paralelo, las pequeñas burlas al caballero - de las que son cómplices sus damas y que imprime en la obra un tono de comedia ligera- tal vez interpretables un primer momento como recurso para ocultar su intervención en el proceso de crecimiento del joven Saintré, anuncian pues de fondo un tono que se tornará progresiva y explícitamente acre ${ }^{13}$.

En efecto, la interacción entre la Dama y el joven se produce casi desde sus inicios en un ámbito discursivo del que no está ausente la burla -y en el que aparece explícitamente convocado el término «farser» como señala Joël Blanchard (Blanchard, 1995:9)-, y que conlleva una banalización, aun leve, del muchacho, sin duda ignorante frente a la experiencia acumulada por Belle Cousine.

Y es en el terreno de la semiótica gestual -que en la primera parte de la obra se articula sobre signos discretos y convenidos, revelándose un discurso en paralelo y un juego de ostensiones y ocultamientos mediante los cuales se desarrolla la comunicación entre la Dama y su joven caballero-, donde la relación comienza a destruirse: la iniciativa del caballero de elegir una empresa y un emblema que se convierta en su marca de identidad, es puesta en cuestión por la Dama. Una opción, la del joven Saintré, que se revela síntoma, aun incipiente, de autonomía, pese a su imbricación en el grupo y su fidelidad a la Dama.

«Avez vous levé emprinse et deppartie ça et la sans mon sceu et sans congié? Jamais, tant que vive, de bon cœur ne vous ameray»

Qui fust esbahy de cs parolles? Certes, ce fust il, car il ne savoit se c estoit par joyeuseté ou par ire. (La Sale, 1995: 406).

Desfases y alteraciones en el juego de perspectivas donde lo que la Dama interpreta como traición del joven señor de Saintré, no es sino fruto de una mirada condicionada por

\footnotetext{
${ }^{13}$ Se advierte la subversión de las narraciones morales para ilustrar lo que consideraba virtudes romanas esenciales -algunas de las cuales recuerdan los Facta et dicta memorabilia de Valerius Maximus. Lo que hay de fondo es la puesta en cuestión de la autoridad del tutor, introducida desde la nouvelle, que narra hechos recientes y que no se halla exenta de una dimensión moralizante (Leglu, 2011)
} 
la perspectiva de un yo constructor -Pigmalion- que predetermina la razón de ser del «otro» reduciéndolo a la condición de «criatura» ${ }^{14}$.

Se ha producido una ruptura de moldes no tanto a través del personaje del caballero, como de la propia dama, mostrada en su empeño de actuar como las grandes Dominae de las novelas corteses, que vuelven a ser convocadas pero desde una distorsión de lo que originariamente habría sido su papel, muy especialmente en las novelas en lengua $d$ oïl. ${ }^{15}$ Una deformación que ya observábamos al hilo de la mención que hacíamos a la obra de Chartier y al acercarnos a la de Villon. En este caso se trata de la tiranía, finalmente develada, de la Dama inicialmente benéfica que a modo de réplica distorsionada de las grandes damas de antaño, actúa como una «reina Ginebra» arbitraria y caprichosa con respecto a su caballero, por otra parte enunciado como el mejor de entre todos ${ }^{16}$.

En lo que a Belle Cousine respecta, junto con la negación de una conducta que el narrador inscribe en el tiempo de la narración, ese tiempo presente al que antes nos referíamos, se produce también una negación progresiva de las formas literarias a través de las cuales esos modelos habían venido cobrando cuerpo. O tal vez para ser más exactos las de aquellas obras que retoman las fórmulas discursivas de las obras «fundadoras». Desde este contexto podemos considerar al Saintré como una empresa de reformulación operada en dos niveles: el humano y el estético.

La «deconstrucción» de la Dama se produce mediante la ostensión progresiva de sus comportamientos de fondo «anti-corteses»: su disconformidad ante la subversión de sus expectativas es expresada a través de la mala taciturnitas que la conduce a abandonar la corte ${ }^{17}$. El mundo bucólico y pacífico en que se refugia no es otra cosa que el pretexto para dar satisfacción a sus caprichos, y a su sensualidad, negando el espacio social con respecto al cual hasta entonces se había venido inscribiendo: la falta de atención de la Dama no sólo a su compromiso con el joven caballero, sino con sus funciones dentro de la corte, algo que de lo que Iseo se lamentaba durante su permanencia en el Morrois, al atenuarse los efectos de la pasión-filtro.

Ahora bien, si en el Tristan el bosque constituye una suerte de punto de fuga para mostrar la proyección de los héroes hacia un absoluto que supera con mucho la contingencia del espacio inmanente, el Saintré, muestra en un discurso -de cuya construcción no está ausente una mirada irónica por parte del narrador, como antes habíamos apuntado-, a una dama banalmente orgullosa, herida en sus intentos de constituirse en ese absoluto.

\footnotetext{
${ }^{14}$ Resalta de fondo la colusión entre dos concepciones: los fundamentos del amor cortés y un individuo naciente que rechaza los excesos manipuladores de la dama. Los riesgos en esta época de ser formado por una Dama (Taylor, 1994).

${ }^{15}$ No podemos olvidar en este sentido que el amor cortés pasa por una dinámica de iniciación en la que le son impuestas al héroe una serie de pruebas conducentes a canalizar sus pulsiones de dominio, tras las cuales gozaría del amor de la Dama. La cortesía se mostraba en las primeras novelas de Chrétien como un terreno en el cual el héroe ejercita su libertad frente a algunos de los parámetros que rigen al grupo, muy especialmente en lo que concierne a su dimensión suntuaria y narcisista. En el caso del Caballero de la Carreta, Ginebra actúa como maestra iniciática que, en medio de su arbitrariedad, se convierte en factor dinamizador de un héroe que se revela superior en valor al resto de los caballeros artúricos. Bien es verdad, como antes hemos indicado, que en la obra Chrétien no deja de mostrar una distancia irónica en algunos episodios, pero volvemos a recordar lo que dijimos en la nota 1 sobre la función de la prohibición en la construcción del héroe y de la sociedad.

${ }^{16}$ El Lai de Lanval presenta ya en el siglo XII a una reina Ginebra que bajo el rostro de la cortesía oculta sus ansias manipuladoras y lascivas.

${ }^{17}$ Esta situación discursiva la podríamos reconocer más adelante en La Princesse de Clèves.
} 
Para subrayar la dimensión degradadora de dicha dinámica de inversión el narrador introduce al personaje de un abad: un hombre identificado como hijo de burgueses enriquecidos, cuyos recursos han podido procurar una abadía a su vástago. Su extracción social permite a la Dama ejercer sobre él su poder omnímodo, reemplazando de este modo la relación de dominio a la que había venido sometiendo al joven Saintré.

A través del personaje del abad joven, robusto y de orígenes burgueses, cobra cuerpo el proceso de degradación de la dama: su cambio de orientación, y su doblez. Su presencia contribuye por otra parte a imprimir un giro definitivo en las situaciones y motivos sobre los que se asienta la narración. Podríamos decir que este personaje se inspira en dos tipos que emanan del fabliau $^{18}$ : a partir de su entrada en escena, el cuerpo y lo corporal es mostrado en el despliegue de su carnalidad -en todos sus placeres de la comida y el sexo-, en una oposición radical a la ascesis y a la canalización de las pulsiones amorosas preconizadas por el amor cortés. Es de alguna manera el factor a través del cual el narrador introduce lo que podríamos llamar una discursivización de los «realia», que imprime un cambio de tono dentro de la narración. El detallismo narrativo se desplaza desde la pintura del torneo, de la batalla en la cruzada que imprimía un indudable tono épico a la narración, hacia el cuadro de interiores, o de género. La descripción, casi cinematográfica, de las ceremonias de la corte, de su aparato, de los emblemas y atuendos de los caballeros da paso al bodegón y a la descripción prolija de comidas, mesas y manteles. De la misma manera que los lances caballerescos, en los que el primero ha demostrado su excelencia, se ve reemplazado por un tipo de lucha confiada a la fuerza física, más vinculada al mundo de los campesinos que al de los gentilhombres.

Inversiones a través de las cuales se prefigura la inversión esencial: la producida en el personaje de la Dama que ha reemplazado su juego cortés inicial por un burdo triángulo amoroso. Ahí reside la retractación de la que hablábamos con respecto de los grandes ideales inicialmente enunciados desde un tono sublime. Se produce una reducción mezquina del amor, que hace evidente la miniaturización de que Belle Cousine había pretendido hacer objeto al héroe, el cual por otra parte se ve exonerado por el narrador, que va suprimiendo de su nombre la calificación de «Petit» para convocarle como Saintré a partir del capítulo 40, y como «Seigneur de Saintré» a partir del capítulo 120 (La Sale, 1995a: 374), tras haber sido armado caballero por el rey de Bohemia ${ }^{19}$.

Desde ese respeto es el propio locutor principal quien convierte a su personaje en narrador intradiegético para así permitirle sancionar con el castigo público a quien ha traicionado su buena fe y el fundamento mismo de la escala de valores que forman parte del universo cortés: valiente en la lucha, fiel y leal hacia la dama, y generoso en el agradecimiento que le muestra, el joven Saintré no deja de instituir a Belle Cousine en desti-

\footnotetext{
${ }^{18}$ Se trata del cura infiel que acaba siendo un obstáculo para la estabilidad familiar, y el burgués que se revela incapaz de acceder a los valores más elevados, reservados a los nobles. Por otra parte no olvidaremos que la nouvelle, en la línea inaugurada por el fabliau, ofrece una visión de la mujer filtrada por una perspectiva decididamente misógina, opuesta a la gineolatría cortés: así, junto a la Domina que emana de la cortesía, se desarrolla un tipo femenino taimado y lúbrico, presto a engañar a sus maridos, instancias de autoridad, que en su origen -y otra vez nos referimos a los fabliaux - encarnan ese universo burgués, entrevisto como envés de la cortesía: avaricia, celos, confiado con los maledicentes y envidiosos.

${ }^{19}$ Ver igualmente el capítulo 126: «Comment le Seigneur de Saintré vint a Paris devant le roy» (La Sale, 1995a: 388).
} 
nataria última de sus hazañas y empresas, y aun de aquellas decisiones tomadas desde el ejercicio de su autonomía. El personaje de Saintré podría ser entrevisto como reelaboración moderna de dicho universo en su dimensión más noble, opuesta a su banalización como herramienta de manipulación al servicio de intereses espurios.

\section{2.a. Subversión y cambios de tono: la comicidad y la falta del héroe}

En un procedimiento que se remonta a tiempos pretéritos y que, como veremos más adelante, se repite en el siglo XVII, la narración cómica se revela como una forma discursiva que, desde la distancia que la comicidad permite, aborda los aspectos menos «nobles» del hombre y del mundo en que éste se inscribe (Suárez, 2006). Ese juego de subversión crea el contexto discursivo para lo que sería el núcleo esencial de la acción: mostrar los discursos de la dama, y los implícitos que de él se desprenden. Así como la transmutación del pacto de fidelidad y secreto (pálido eco de la gei $^{20}$ ) en un juego de tiranía desvelado mediante «el teatro dentro del teatro». Los cambios de la dama son entrevistos como síntomas de su condición mudable, uno de los grandes pecados tipificados en el universo cortés y que ya Villon había puesto de relieve en la Balada a su Amiga.

Trampantojos que son vía para mostrar la contradicción humana. Juegos de oposiciones, enfatizados por enumeraciones y descripciones que se inscriben en el terreno de lo hiperbólico. Y un retrato de sentimientos y del juego amoroso enunciado en su desarrollo inicial desde su vertiente contraria -la lítotes.

Al igual que el Testamento de Villon, el Saintré es un cuadro formado por los contrastes, por juegos internos de oposiciones: lo aparente, lo real; los juegos de máscaras en el centro mismo de la corte -los mensajes «cifrados»- que evoluciona hacia su dimensión menos noble en un juego de discursos contradictorios.

La obra de La Sale nos sitúa ante un conflicto producido por la renuencia de la Domina a aceptar los atisbos de autonomía del héroe. Y ello se traducía en una atenuación de su condición de garante de un proceso de construcción/ individuación. El joven caballero que inicialmente se define desde la mirada de ésta se ve reducido a la perplejidad ante la reacción del otro, que contrasta con los presupuestos que él mismo atribuye a su papel: el muchacho acaba por encontrarse en tierra de nadie, tratando de reparar su «falta».

La falta del héroe en este caso particular reside en el ejercicio de una libre opción, que incluso el rey parece también recriminar. Se trata en realidad de una discusión sobre la libertad del individuo, el cual poniendo en evidencia no tanto la cortesía como los esquemas en los que ésta acaba degenerando continúa pese a todo defendiendo los valores aristocráticos del honor y la fidelidad. Podríamos por tanto hablar de una falta «necesaria» que por un lado manifiesta ese desequilibrio entre la perversión de un modelo de

\footnotetext{
${ }^{20}$ En la mitología celta la geis es una prohibición que el ser sobrenatural impone al humano con quien establece una vinculación, consistente normalmente en mantener el secreto sobre la relación que los une, de tal modo que la transgresión de dicho pacto podría conducir a la muerte, o a la desaparición de los lazos entre ambos. En el marco del discurso cortés, dicha geis, el secreto, obedecería no sólo a la necesidad de ocultar una relación adúltera, sino también la separación entre el mundo contingente de la corte y el universo trascendente en el que se inscriben los amantes. La imposición podría asimismo actuar como mecanismo que modula las eventuales pulsiones de dominio/ posesión del amante sobre la Dama.
} 
alianza cuyo objetivo sería el desarrollo del hombre, pero que se revela finalmente aprisionador, y por otro la capacidad de acción que el héroe puede llegar a alcanzar.

$\mathrm{La}$ «falta del héroe» es un motivo recurrente en la literatura: recordemos los errores encadenados de Perceval: su partida brusca de la casa materna, los despropósitos que después se advierten. Todo ello debido en parte a la ignorancia a la que el encierro materno lo ha confinado - una red de silencio que se traduce en la ausencia de presupuestos a partir de los cuales configurar sus decisiones discursivas, y que se halla en la base de su fascinación por la caballería artúrica. En el caso de Saintré, la decisión del joven caballero es interpretada por la Dama como «error», pero sólo a causa de los deseos de ésta de mantener a su pupilo encerrado dentro de los límites estrictos de los presupuestos que ella le proporciona. Ello mostraría el lado más perverso de la cortesía ${ }^{21}$, degradada en una acción constrictora, que en algunos aspectos podría recordarnos a la madre del joven caballero galés, pero sin que haya lugar para su acción reparadora posterior ${ }^{22}$.

Saintré se ve sin embargo reducido a la orfandad -esa tierra de nadie a la que acabamos de referirnos: tal es el castigo y la condena recibidos por el héroe, una situación que acabará por revelarse como paso previo a la liberación. Y en esa liberación volvemos a advertir la presencia de esa dimensión punitiva del charivari, presente en textos anteriores donde los personajes que encarnaban los avatares negativos de la locura, o aquellos agentes cuya conducta suponía una alteración de los moldes tradicionales -les Sotz Nouveaux- eran vencidos o cuando menos puestos al descubierto en sus maquinaciones por parte de los personajes vinculados a los valores tradicionales, ya lejanos -Bontemps-. Una acción que se dejaba asimismo sentir en la desfiguración de que el sarcasmo de Villon hace objeto a la amante cruel y traicionera, cuyo rostro se ve progresivamente afectado por el paso del tiempo que el locutor, por su parte, no deja de asociar con la propia instancia femenina ${ }^{23}$.

La burla es el recurso que permite castigar el engaño y mostrarlo en toda su duplicidad: una burla articulada a partir de una narración introducida dentro de la narración principal en la que Saintré se ve constituido en narrador que desvela datos que conciernen a una dama a la que todos los narratarios a quienes se dirige serán capaces de identificar.

De esta manera, en tanto que la dama se ve finalmente excluida del grupo que ella misma había rechazado en su espacialidad y en sus propios valores, Saintré aparece constituido en ser de razón, respetado y apreciado por sus contemporáneos tal como indica el narrador en su epílogo, si bien en algún momento de su trayectoria se ve investido de cierto sesgo marginal, como lo están todos los héroes. No obstante, a diferencia de otros héroes anteriores y posteriores, no podemos decir que se halle desvinculado del orden del mundo que habita.

\footnotetext{
${ }^{21}$ Recordamos una vez más que los planteamientos iniciales de lo cortés y la cortesía se revelan en su reelaboración en la zona de lengua d'oül, y muy especialmente en el discurso narrativo, como una integración entre la dimensión guerrera y la dimensión sentimental, así como un aprendizaje que permitía al guerrero canalizar sus pulsiones dominadoras y narcisistas.

${ }^{22}$ La relación entre Saintré y su Dama adquiere un sesgo vertiente materno-filial que amenaza con tornarse una fuerza que infantiliza al héroe (Emerson, 2011; Galderisi, 1999).

${ }^{23}$ Una instancia a la cual el propio Villon había identificado en otros discursos como garante de la pervivencia y la estabilidad en medio de los envites del azar (Ballade pour Robert d Estouteville).
} 
El siglo XV constituiría una etapa relevante de ese proceso de construcción del héroe, del individuo iniciado a finales del siglo XII en el contexto del humanismo medieval, en cuyo marco había nacido el roman.

En ese contexto, la dicotomía entre falta y la libertad es una vieja cuestión que adquiere formas diversas según la época: si Chrétien proponía, en El Cuento del Grial, a un héroe cuya falta residía en su adhesión irreflexiva a los presupuestos de la caballería artúrica $^{24}$, que desde la fascinación que sobre él ejercen le impiden tomar conciencia de su propia identidad y de su propia misión, el Saintré, muestra la confrontación entre esa libertad, que Perceval al final de su proceso de aprendizaje parece estar ya en disposición de ejercer, y la perplejidad de un héroe que, habiendo superado los distintos grados de iniciación, se confronta a una réplica desgastada de los modelos humanos y morales que han sido sus garantes en dicho proceso de construcción. Pierden de este modo su dimensión dinamizadora para tornarse canal de constricción.

En el Saintré, la lectura de la tradición se revela irónica y fragmentaria, -con frecuencia paródica-, pero también acechada por cierta conciencia de orfandad y desasosiego tras la que se esconde una especie de horror vacui al que subyace un estado de ánimo confuso, -entre hastiado y perplejo-, que para enunciarse recurre al reciclaje cultural. La intertextualidad, el pastiche o el collage, abren vías para recuperar a los «antiguos» referentes que permiten de alguna manera organizar, siquiera por la vía del contraste, un mundo que amenaza con tornarse farragoso, si no hostil, a los presupuestos con respecto a los cuales se había venido definiendo un modelo humano. En este marco, el locutor, a partir de un discurso cuya dominante es el estilo elevado propio de la épica y de la novela heroica, introduce paulatinamente una tonalidad totalmente distinta: el cambio de escenario y de personajes, así como la presencia de los realia son factores que desplazan el discurso hacia un tono medio, incluso bajo, mostrando una cortesía decadente. Pero, como también hemos venido indicando, esto no implica una negación radical de los valores corteses: convocados por el narrador desde la nostalgia y la constatación de la atenuación de su fuerza en el mundo en el que su personaje y él mismo se inscriben, dichos valores permanecen en un héroe, en ningún momento desarraigado de su tiempo, que toma conciencia de la degradación de la instancia con respecto a la cual había venido construyéndose, pero sin por ello renunciar a la dimensión más profundamente vigorosa de una tradición.

Las formas discursivas vigentes son explotadas en sus distintas posibilidades, creando formas nuevas a menudo a partir de mezclas e hibridaciones, que acaban por revelarse lugares de experimentación literaria. Éstos responden por su parte a nuevos interrogantes vitales traducidos en la necesidad de encontrar respuestas estéticas, humanas, jalonado por confusiones entre las identidades de personaje, narrador y autor.

\footnotetext{
${ }^{24}$ En este sentido recordemos que ya los héroes de Chrétien, sobre todo los últimos, se encuentran entre la marginalidad y una posición de preeminencia dentro de la Corte. En efecto, Lancelot renuncia a la dimensión mundana del honor caballeresco -ver nota 1-, pero no a su realización como caballero, que él asocia con su vinculación a la Dama. Desde ahí estará en disposición de garantizar la pervivencia de la corte. Paralelamente a ello, el hecho de que Perceval no pueda al principio de su aventura acceder a su identidad, y a su misión, se debe a su atracción excesiva hacia lo caballeresco al uso, de la misma manera que su proceso de maduración se advierte en la actitud de libertad e independencia en sus decisiones, que pueden revelarse disonantes con respecto al marco de la corte («Et Percevax redit tot el», v. 4727).
} 
Podríamos hablar de juegos de identidad vinculados a lo efímero. A la dicotomía entre sueño y vida, sobre todo a la dificultad de establecer sus límites. La aprehensión de las cosas se ve condicionada por la sospecha de la ilusión; la dinámica del esfuerzo por la del desengaño. Los juegos de ilusiones narrativas -que hemos visto en el Saintré, y que no dejábamos de atisbar en el «yo» proteiforme de Villon-, funcionan como encrucijada de discursos varios y variados, a partir de los cuales el autor, mostrando sus entresijos, recurre a juegos de imitación y palinodias.

Recursos retóricos como oxímoros y antítesis, que expresan la contradicción. La hipérbole y la desmesura, pero también su «contrario», más bien su complementario -la lítotes y las atenuaciones-, que generan claroscuros discursivos y desenlaces abiertos. La ironía y las paradojas como confluencia de voces cuya confrontación se hace eco de la ambigüedad.

Se producen búsquedas susceptibles de proyectarse hacia el punto de fuga hacia los grandes valores ya sean éstos de orden trascendente, estético o político. O bien hacia un espacio umbral, un espacio «otro», donde se sitúa lo más excelsamente divino, o lo más abyectamente humano, polos en torno a los cuales oscila el movimiento del héroe. Las búsquedas se decantan por tanto en direcciones distintas -orientadas hacia la inmanencia más cruda, o hacia el punto de fuga de lo trascendente. Y la huida se torna a menudo simbólica, a través del disfraz y la máscara, o mediante la inscripción en el terreno de lo ritual. Esta última sería la opción de Saintré cuando se aferra a los valores internos de la caballería cortés, en tanto que el personaje-locutor del Testamento se inscribe en la marginalidad, personal y social, al enunciar la abyección de la amada infiel. La misma abyección que aun provisionalmente había «expulsado» al joven caballero del universo que hasta entonces había habitado y que confería sentido a su propia condición humana.

\section{EL SIGLO XVII: EL TIEMPO, EL CAMBIO Y LA IDENTIDAD}

Volveremos a identificar algunos de estos rasgos que hemos ido señalando en obras dispares en apariencia, como el Testamento de Villon o el Saintré, en otras producciones literarias que surgen en otro momento de transición, decisivo para la cultura francesa: la bisagra que propicia el tránsito del siglo XVI al XVII. Si bien se trata de proyectos discursivos diferentes que cobran cuerpo en un marco filosófico y humano distintos, no es menos cierto que en ambas tiene lugar ese juego de desgaste-renovación constatable en una y otra época. Ello se muestra en una suerte de afinidad en cuanto a los recursos retóricos que ponen en pie los discursos de una y otra época: éstos se hacen eco de una tensión entre instancias ante la que le héroe se debate entre una sociedad cuyos valores parecen haberse debilitado y un proceso de búsqueda, humana y estética, que trata de hallar nuevas vías ante modelos narrativos agotados: son rasgos que advertíamos en el Saintré y que también identificamos en la Histoire Comique de Francion, una obra compuesta en el primer tercio del siglo XVII por Charles Sorel, un autor vinculado al ideario libertino, una de las corrientes de la época que trata de recoger algunos de los últimos resquicios de los presupuestos humanistas ${ }^{25}$.

\footnotetext{
${ }^{25}$ Sorel se inscribe en el movimiento intelectual de los libertinos, que tienen en cuenta buena parte de los ideales humanistas. Esta escuela comienza a cobrar cuerpo en Francia a finales del siglo XVI, momento en que son
} 
Al igual que el Saintré en su momento, esta obra supone un punto de inflexión en el devenir del discurso narrativo. El autor se sirve del término roman, recuperando el término tradicional, que daba cuenta del proceso de construcción de la vida de un héroe, pero éste es modificado mediante el término «comique», en tanto que perspectiva que, como antes habíamos señalado, ofrece esa distancia necesaria para propiciar un mayor acercamiento a la realidad, por cuanto que permite romper por la vía de la distorsión los moldes falsamente idealizados.

Recuperando recursos y posicionamientos a los que anteriormente nos hemos referido -los juegos de superposición e hibridación-, Charles Sorel elabora su Roman Comique de Francion en 1623 en torno a un personaje cuya configuración hunde sus raíces en las producciones literarias anteriores -entre las que se encuentran la epopeya rabelaisiana ${ }^{26}$-, y cuyo desarrollo se inscribe en un proyecto heroico vinculado al tipo del «generoso»-un nuevo tipo de héroe, que mediante el ejercicio de la virtud se hace dueño de su libertad y sus decisiones-, enriquecido en el caso del personaje soreliano por la vertiente estética, y por una dimensión carnavalesca que muestra su vinculación con los héroes utópicos, y le hace capaz de intervenir en el mundo que le rodea a través de la risa y la burla empleadas como armas mordaces. Al igual que su predecesor, Sorel opta por la coexistencia de tonos y estilos. De esta manera el escritor lleva a cabo su doble empresa, que en realidad converge en un proyecto único: proponer una forma nueva de escritura, vinculada a un tipo humano capaz de intervenir en la construcción de una sociedad también nueva ${ }^{27}$. La palabra -tanto la palabra estética como la palabra cotidiana- se halla de esta manera vinculada al modo de ser del hombre y a su manera de habitar y construir su mundo.

Pero en el caso de Sorel la preocupación estética se ve más acentuada que la obra del chinonés: para el primero, escritor de profesión, la renovación del modelo novelesco es una vía para romper con los moldes cultivados en la época, que el autor considera metáfora de una sociedad anquilosada en usos desgastados que no son ya sino un pálido reflejo de los valores que originalmente evocaron.

Se trata, en efecto, de una obra que contiene ecos de un proyecto utópico construido con el concurso de la comicidad, pero, al igual que en la saga gigantesca, las continuaciones sucesivas dejan sentir la atenuación de la capacidad transformadora de su héroe (Suárez, 2006): la última de las versiones del Francion contiene una suerte de retractación, un distanciamiento con respecto a la propuesta humana y estética -en la que se deja sentir buena parte del legado humanista- construida en el proyecto inicial. Una maniobra tal vez articulada desde el escepticismo del autor ante su eventual constatación de la inviabilidad de su propuesta, o desde los intentos de protegerse en un momento en que pierde a su protector, y en el que la apertura que había caracterizado el primer humanismo no es ya sino un recuerdo.

integradas las propuestas que Pietro Pomponazzi había elaborado en la Escuela Paduana a finales del siglo XVI, y en las que se propone una ruptura clara entre la reflexión filosófica y la teológica, aspecto que es percibido por el movimiento libertino como liberación del hombre frente a dogmatismos, y que permite al hombre situarse en el plano de lo «divino», recogiendo de este modo la frase de Epicuro: «vivir como dioses».

${ }^{26}$ Los libertinos no ocultaron en ningún momento su admiración hacia Rabelais.

${ }^{27}$ El nombre del héroe, Francion, se remonta a Francus, héroe epónimo, primer rey de los Francos, cuyos orígenes se remontaban a la legendaria Troya. 
Su héroe, inicialmente investido por el poder de la risa y la locura presentadas como síntoma de superioridad del personaje, se ve progresivamente degradado por otro avatar de la locura en su vertiente más perniciosa, provocada por su vinculación al discurso novelesco y filosófico que en su época son reconocidos como dominantes. Dicha atracción/ asimilación se traduce en un deterioro de su condición intelectual: la del narrador -que construye una asociación con el personaje- sería una argumentación cuya finalidad es mostrar el envilecimiento moral e intelectual que dicho universo estético produce en el héroe. Sorel muestra de este modo una palabra caduca, creadora de ficciones engañosas, vigente en una sociedad que ha reemplazado el ser por el parecer, y sitúa al héroe ante un conflicto que acaba resolviendo desde la transgresión. Es esa opción la que garantiza al personaje una total libertad en el ejercicio de una misión crítica, operada a través de la risa, el arma que fustiga, desvela usos y prácticas nocivos para la sociedad, despojándolos así de pertinencia y fuerza. Una manera de expulsar el pharmakos, marcada como en las obras anteriores por un claro acento charivárico.

Situado en un espacio liminal desde el que adquiere un mayor grado de perspectiva y lucide $z^{28}$ y desde donde queda configurado como héroe alternativo, Francion accede finalmente al amor de una dama que simboliza la perfección, susceptible por otra parte de ser asimilada con la estética. Pero ya en la segunda parte, el héroe aun cuando cuenta con la posesión de Naïs, el objeto precioso, acaba perdiéndose de nuevo en el laberinto de la conquista y el engaño compulsivos: frente a la acción constructiva de la locura y el caos que acabaría imponiéndose en la primera parte pese a las distintas caídas del héroe, la continuación de la historia muestra al héroe desafiando a Fortuna precisamente cuando la suerte se le muestra favorable. La dinámica redundante del «burlón»-que cobra cuerpo, al igual que en obras anteriores, en una errancia física- se convierte en este nuevo contexto discursivo en el reflejo de una disonancia interna e inconsciente. El héroe se instala en ese espacio umbral, al que antes nos referíamos, que ha venido a sustituir al Absoluto estético y humano, hacia el cual se había proyectado inicialmente.

Presa del tedio, el héroe sitúa la figura de la amada en un segundo plano para dejarse fascinar por otras instancias: Francion se instala en un juego donde la pasividad se entremezcla con conductas «hiperactivas», y donde la falta del héroe consiste precisamente en su pérdida de una perspectiva de integración que en otro tiempo le había otorgado la capacidad necesaria para asumir una dinámica y un discurso de liberación y de independencia con respecto a la mediocridad y la opinión de los otros.

Francion permanece en el interior de sus propios espejismos, en una aventura banal y banalizada, que es réplica simiesca del proceso de construcción asumido anteriormente, y que le ofrece una auto representación falseada también. En este sentido, la práctica ausencia de precisiones temporales en la narración es un recurso para mostrar la ucronía, un tiempo detenido en cuanto a sus posibilidades de progreso. Esta vez la disipación del héroe tiene lugar en el decorado pastoril, construido desde una aprehensión negativa del bucolismo, más focalizado como despreciablemente rústico que

\footnotetext{
${ }^{28}$ El episodio de la orgía supone una acción ritual en la que, mediante un proceso de asilamiento del mundo externo que hace posible un movimiento de introspección, el héroe se ve revitalizado en sus fuerzas creadoras y dinamizado en sus procesos de búsqueda y construcción.
} 
como edénico ${ }^{29}$. El devenir de Francion se desarrolla de acuerdo con una dinámica inversa a la del proceso de unificación descrito en la primera versión de la novela: involución provocada por el tedio y expresada a través de un modelo estético-la novela pastoril-, denostado por el autor.

Francion no sólo muestra las fallas de un discurso falsamente idealista, y el modo en que éste afecta al héroe ${ }^{30}$, sino las contradicciones internas que condicionan sus decisiones hasta llegar a inscribirlo en una dinámica de degradación, pese a los episodios en los que ha hecho gala de su condición de «generoso» (libertad/ consciencia). Una tensión interna expresada por la contraposición de tonos divergentes.

\section{A MOdO DE CONCLUSIÓN: LOS JUEGOS DEL CLAROSCURO}

Un procedimiento semejante al que había sido emprendido por La Sale cuando trata de mostrar el deterioro de un esquema inicialmente entrevisto en clave de crecimiento, progresivamente reducido a una serie de argumentos que tan sólo sirven como pretexto para una dinámica de manipulación.

En este sentido Saintré es el héroe, a caballo entre dos épocas, que se mantiene íntegro en sus valores y decisiones, pese a sus perplejidades, provocadas éstas por la negativización de la Dama. Una dinámica que habíamos observado igualmente en su contemporáneo Villon, cuando éste muestra a su personaje como víctima de la degradación del espíritu cortés, al tiempo que como autor del castigo a quien en aras de esa instancia ejerce sobre él una acción denigrante y devastadora.

Si la gran aportación de la cortesía, sobre todo en la evolución que ésta experimenta en las regiones del norte, había sido la canalización de las facetas de la proeza en las armas y de la civilidad -civilidad amorosa y social-, ambos autores mostraban el desgaste del agente que vendría a propiciar dicho proceso. No obstante, y ello constituye una diferencia sustancial de la obra de La Sale con respecto a la de Villon, el Saintré muestra junto con dicha acción degradadora la capacidad del individuo para, desde el ejercicio de su voluntad y su libertad, remontar la situación más allá de la bajeza y la vulgaridad en la que, a pesar suyo, se ve sumido. La abyección aparece situada en el exterior del héroe y los nuevos moldes literarios vendrán al rescate de esa tarea depuradora y depurativa.

Por su parte, la obra de Sorel, en su primera versión, muestra a un héroe también capaz de remontar la degradación -que sufren tanto la sociedad como él mismo-. Una degradación expresada a través del relato jocoso, que de nuevo nos retrotrae al fabliau, mediante el cual el narrador mostraba el envés de los discursos falsamente idealistas, para posteriormente abrir la puerta a la voz del personaje principal que -al igual que había hecho Saintré con respecto a Belle Cousine- desvela y fustiga las lacras de una sociedad cuyas consecuencias ha sufrido él mismo. En este sentido la hazaña de Francion consiste en

\footnotetext{
${ }^{29}$ Pese a no haberse despojado del desprecio que desde el inicio de la primera parte muestra hacia los pastores -a los que califica de «gentes brutales»-, Francion no duda en crear falsos mundos adoptando máscaras -entre ellas el lenguaje-, con el fin de acceder a sus deseos más inmediatos: la burla amorosa.

${ }^{30}$ Esto ya le había ocurrido al héroe en la primera parte de su recorrido cuando pierde su ingenio natural tratando de escribir de acuerdo con los moldes retóricos que estaban de moda. Un proceso que nos recuerda a la pérdida de vigor intelectual de Gargantúa cuando lo someten a la disciplina de los profesores «sofistas».
} 
inscribirse en una lógica alternativa que propicia un nivel de consciencia que lo separa de esa mediocridad estética en la que se había visto sumergido.

En esa nueva inscripción consiste la victoria del héroe, que la segunda parte de la obra revela sin embargo efímera: su inmersión en una Arcadia abaratada -una vez más el decorado campestre funciona como revulsivo-, lo degrada en una sucesión de burlas sin trascendencia. La fuerza y la libertad del generoso -elaboración que cobra cuerpo en el primer tercio del siglo XVII y que recogía en buena parte los parámetros del humanismoparecen puestas en cuestión en aras de un juego de fuerzas -internas- que él ya no parece capaz de gestionar y canalizar, como hiciera en otros momentos de su historia.

El narrador lo sitúa en medio de un conflicto que lo aprisiona y del que no parece poder salir airoso sino a través de un desenlace poco verosímil: podríamos hablar de una suerte de charivari intradiegético en el que la situación sin duda desairada de Francion hace posible una reprimenda por parte del narrador, pese al respeto que nunca deja de mostrar hacia su personaje.

Podríamos considerar al Saintré y al Francion como dos obras que se inscriben en los extremos inicial y final de una secuencia cronológica de dos siglos, dos puntos que marcan respectivamente el inicio y el final del humanismo que se desarrolla y esponja a lo largo del siglo XVI. Cada una de ellas muestra el agotamiento de modelos discursivos precedentes desde la voluntad de hallar formas que hagan posible la enunciación de nuevos modelos humanos. En el Saintré se advierte el estallido de una crisis de identidad finalmente reconducida hacia una reformulación del hombre que anuncia esa resurgencia humanista. Una opción, que no cobraba cuerpo en el Testamento, donde el «yo» que confiere unidad a la pieza completa, aparece diseminado por el estallido de un juego de fuerzas que se sustraen a su control.

Francion, por su parte, muestra los últimos atisbos de ese héroe que de alguna manera iba apuntando en el Saintré. Últimos resquicios que acabarán por verse más que atenuados en la segunda parte de la novela soreliana.

Ambas obras, ambas épocas, dan cuenta de un juego de contrarios no siempre pacíficamente resuelto. Puntos de vista contradictorios que convergen en el mismo discurso dando así lugar a la paradoja, que se hace eco de esa tensión, y a la antítesis, que manifiesta esta estructura conflictual generada por las aporías que el yo constata y ante las que trata de posicionarse, y de definirse, en su enunciación.

La evocación de los grandes ideales de antaño muestra a modo de reflejo especular la prestancia de un tiempo ya pasado y su ausencia del tiempo presente. La exaltación del «yo» y sus potencialidades omnímodas - la figura del caballero, o la del generoso a las que acabamos de referirnos- coexiste con la conciencia de la propia finitud: la exacerbación del sentimiento de individualidad, la formulación de los miedos del espíritu, también hiperbólicos, se confronta con el espectáculo aplastante de la multiplicidad que devora.

No es casualidad que en uno y otro momento se advierta la presencia de representaciones voluntariamente deformadas tanto pictóricas como literarias: en el siglo XV las representaciones de la muerte y los cuadros paródicos del Bosco constituían una especie de contrarréplica a la magnificencia de los retratos de los grandes señores; de la misma manera que más adelante actuarían las anamorfosis y los juegos con la perspectiva y el rostro que irrumpen con fuerza en la segunda mitad del siglo XVI y buena parte del XVII. Lo cómico se muestra como función legítima e irrenunciable del arte que construye con- 
tra-argumentos al retrato idealizado del hombre, grande y bello, que desarrollara el humanismo renacentista.

Rasgos - presentes en ambos momentos- que consideramos susceptibles de ser consignados bajo el marbete de «barroquizantes» en el sentido amplio del término.

Sin pretender extender el término, y la noción, de «barroco» a otras épocas de manera indiscriminada y abusiva, sí desearíamos llamar la atención sobre la coincidencia de una serie de recursos discursivos que se hacen eco de cambios, en los que se deja sentir cierto sentimiento de desgaste. Pero junto con él, también la necesidad de explorar nuevas formas de expresión y de vida ${ }^{31}$.

Hemos venido dando cuenta de formas retóricas vinculadas a la contradicción y los juegos del claroscuro ${ }^{32}$, que muestran la pugna entre, por un lado, los repuntes en la consciencia de libertad y autonomía que el hombre adquiere y la constatación de sus límites, por otro. Se trata de juegos discursivos, a menudo explicitados por la vía del metadiscurso, que se sustentan sobre exploraciones y búsquedas en las cuales las contradicciones del hombre son mostradas, más que definitivamente resueltas: de ahí la obra inacabada, abierta, en constante recreación, e incluso en interacción con los destinatarios instituidos por el narrador.

Como hemos venido indicando desde el inicio, buena parte de ese proceso de búsqueda se articula sobre el tratamiento diferencial de formas discursivas vinculadas a universos de sentido precedentes, cuya vigencia se ha visto debilitada. La consideración de dicha diferencia ha sido el hilo conductor que nos ha permitido acercarnos a dos épocas en las que el cambio se hace presente de manera especial. Diferentes entre sí, ambas tienen en común la tensión en ellas producida entre la añoranza de valores debilitados por el paso del tiempo, vinculados a construcciones discursivas y culturales que han perdido su vigor inicial, y los intentos de reformulación en nuevas aprehensiones del hombre y de lo humano.

\footnotetext{
${ }^{31}$ En algunos momentos ambas épocas han sido aprehendidas, incluso evaluadas, como pre- y post-humanismo, tomando siempre como referencia al Renacimiento del siglo XVI, por su parte a menudo asociado con la noción de clasicismo. El siglo XV ha sido visto como el albor del humanismo; en cuanto al barroco éste fue durante mucho tiempo identificado como una mutación defectuosa. Tiempos imperfectos, formas irregulares... consecuencia del estallido del centro de la circunferencia en cuyo centro se inscribía el hombre. La circunferencia de hecho se ha transformado en elipse (Dubois, 1979).

${ }^{32}$ Hay en esto una alusión implícita, y voluntaria, a una dimensión visual que se halla presente en el discurso literario del siglo XVII. Al hilo de esta cuestión no podemos olvidar que el teatro fue uno de los géneros literarios, y culturales, que con mayor frecuencia ha sido vinculado al Barroco, a lo barroco. En el siglo XVII, como ya había apuntado el XV (ver nota 6), el espectáculo teatral se desarrolla desde la voluntad de mostrar las contradicciones y las seguridades del hombre. Y sus pasiones, que pasan a ocupar el primer plano del escenario, de modo que ni lo más bajo de éste se sustrae a la mirada del público. De hecho, una de las críticas de los teóricos del siglo XVI al teatro del XV era el nulo respeto al decoro: otro tanto ocurriría con respecto al teatro de finales del XVI y principios del XVII donde la violencia, física o moral, se mostraba en toda la impresión de realismo que podía ofrecer la ilusión teatral.
} 


\section{BIBLIOGRAFÍA CITADA}

\section{Obras literarias. Ediciones y traducciones}

La SALE, Antoine de (1978): Jehan de Saintré, Jean Misrahi et Charles A. Knudson (introduction et notes), Ginebra, Droz ( $3^{\mathrm{a}}$ ed.).

- (1995a): Jehan de Saintré, Joël Blanchard (édition, introduction et adaptation au français moderne), París, Librairie Générale Française. Coll. Lettres Gothiques.

- (1995b): Jehan de Saintré, Roger Dubuis (édition), Paris, Honoré Champion.

- (2000): Saintré, Felicia de Casas (traducción y edición), Madrid, Gredos.

Sorel, C. (1996): Histoire comique de Francion. A. Schoysman (édition), Paris, Gallimard.

VILlon, François (1994): Euvres, Dominique Aury (édition), Genève, Slatkine.

\section{Estudios citados}

ACCAIRE, Maurice (2004): Théâtre, littérature et société au Moyen Age (Éliane Kotler, éd.), Nice, Serre Éditeur.

DANDREY, P. (2001): Le premier Francion de Charles Sorel ou le «jeu du roman», Paris, Klincksieck.

Debaisieux, M. (2001): «Sous le signe de Mercure: de la thématiue du vol à la fraude littéraire dans le Francion», Charles Sorel: Histoire comique de Francion (Jean Serroy, éd.), Paris, Littératures Classiques, pp. 49-61.

Dubors, Claude-Gilbert (1979): Le Maniérisme, Paris, PUF.

EMERSON, Catherine (2011): «No Way to Treat your Mother: Understanding Petit Jehan de Saintré's Rage», French Studies, 65/ 4, pp. 429-443.

GaLDERISI, Claudio (1999): «La femme et le pantin. La statue de cire du Jean de Saintré», Magie et illusion au moyen âge (Chantal Connochie-Bourgne éd.), Aix-en-Provence, Université de Provence, pp. 159-172.

JEAY, Madeleine (1997): «Le travail du récit à la cour de Bourgogne», Lettres Romanes, pp. 71-86.

Koopmans, Jelle (1997): Le Théâtre des exclus au Moyen Age: hérétiques, sorcières et Marginaux, Paris, Imago.

Leglu, Catherine (2011): «Antoine de La Sale's: the cannonball and the Prince's Head», French Studies, 65/2, pp. 143-155.

LÉvi-STRAuss, Claude (1962): La pensé sauvage, Paris, Plon.

Mühlethaler, J. C. (2006): «D’Enée à Saintré», Conter de Troie et Alexandre. Pour Emmanuelle Baumgartner (Laurence Harf-Lancner; Laurence Mathey-Maille éds.), Paris, Presses Sorbonne Nouvelle, pp. 115-133.

Radcliffe-Brown, A.R. (1952): Structure and Function in Primitive Society: Essays and Addresses, Glencoe, Illinois.

Rosellini, M.; SALVAn, G. (2000): Le Francion de Charles Sorel, Paris, Atlande Lettres XVIIème siècle.

SuÁREZ, María Pilar (1998): «La mère et la femme fatale chez Villon», Bien dire et bien aprandre (Centre d'Études Médiévales de Lille III), Lille, Presses Université de Lille, pp. 237-245.

— (2006) «Les Enjeux du Décepteur: Panurge, Gargantua, Francion», Thélème, 21, pp. 197-210.

- (2008) «Le Jeu de la Feuillée et la dissonance du sujet», Neophilologus, 87/ 3, pp. 23-34.

- (2010) «La quête, la fuite et la terre gaste», Lors te metra en la voie... Mobilité et littérature au Moyen Age (Carlos Carreto, éd.), Lisboa, Universidades Aberta, pp. 97-104.

- (2011) «Reprises parodiques et configuration stylistique: le théâtre d'Adam de la Halle», Cultures courtoises en mouvement (Isabelle Areseneau; Francis Gingras, éds.), Montréal, Presses de l'Université du Québec, pp. 190-200. 
SzkILNIK, Michelle (2003): Jean de Saintré. Une carrière chevaleresque au XVe siècle, Genève, Droz («Publications romanes et françaises » 232).

TAYLOR, Jane H. M. (1994): «Courtly patronage subverted: Lancelot en prose. Jehan de Saintré», Medioevo Romanzo, 19/3, pp. 277-292. 